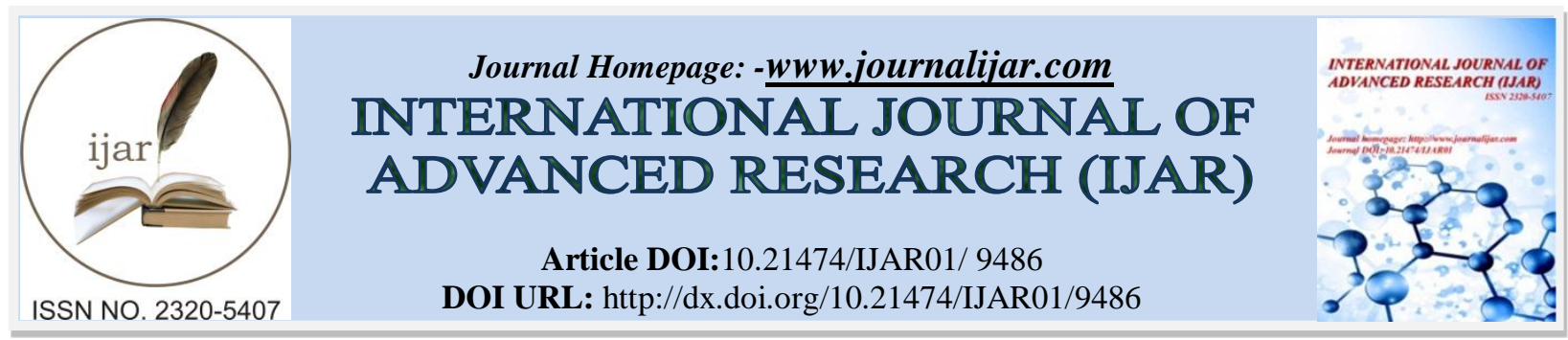

RESEARCH ARTICLE

\title{
ANTITHYMOCYTE GLOBULIN, METHYLPREDNISOLONE AND CYCLOSPORINE IS AN EFFECTIVE TREATMENT IN SEVER APLASTIC ANEMIA.
}

\author{
Basam Kamal Samad ${ }^{1}$, Hussein Jasim Dadoosh Al-janabi ${ }^{2}$ and Qusay Sami Ahmed ${ }^{3}$. \\ 1. A specialist physician at Al-Nuaman Teaching Hospital. \\ 2. A general surgeon at Al-Nuaman Teaching Hospital. \\ 3. Autolarygological specialist, (Audiology).
}

\section{Manuscript Info}

Manuscript History

Received: 05 June 2019

Final Accepted: 07 July 2019

Published: August 2019

Key words:-

Aplastic anemia, Antithymocyte globulin, Bone marrow.

\section{Abstract}

Background: Immune suppressive therapy in severe aplastic anemia is considered now a standard treatment and it could be an alternative to the hemopoietic stem cell transplantation.

Patients and methods: Thirteen Iraqi patients with severe aplastic anemia were included in this study. The place of work was in national center of hematology and center of bone marrow transplantation. They were treated with antithymocyte globulin infusion for 5 days, then continued on oral prednisolone for 28 days. The monitoring of the patients was done by complete blood count.

Results: The response to the treatment was observed in 7 patients. 53\% had CR and 38\% had PR there was significant improvement in the WBC and platelet counts, but there were no significant changes in the HB levels. There was no difference between sex in response to treatment. Those patients who were considered non responders were six, the death rate was $15 \%$ and allergic reaction occur in one patient $7 \%$.

Conclusion: Antithymocyte globulin, methylprednisolone and cyclosporine is an effective treatment in severe aplastic anemia.

Copy Right, IJAR, 2019,. All rights reserved.

\section{Introduction:-}

Aplastic Anemia (AA) is described as a severe, potentially fatal, hematological syndrome, characterized by hypo or aplastic bone marrow associated to peripheral pancytopenia ${ }^{(1)(2)}$.

The estimated incidence of AA in Western Countries is 1-2/million population/year and it is reported to be lower in childhood than in older ages ${ }^{(3)}$.

In about one third of the patients, suspicion may be directed to a particular agent, usually a drug or virus. Thus in at least two thirds of patients no etiological agent can be identified ${ }^{(4)}$. However, it can be Aplastic anemia categorized into two groups: congenital forming $20 \%$ of cases. like Fanconi's anemia, and dykeratosis congenita ${ }^{(5)}$; acquired constituting $80 \%$ of the cases. This type includes: idiopathic, infectious causes such as hepatitis viruses, Epstein-bar virus, HIV $^{(6)}$, and mycobacterial infections ${ }^{(5)}$, toxins, drugs such as chloramphenicol ${ }^{(6)}$. 
The most commonly accepted theory is the autoimmune hypothesis; aplastic anemia seems to develop secondary to the hematopoietic cell destruction by immune mechanisms ${ }^{(7)(8)}$.

Therapy for AA essentially consists of three modalities- stem cell transplant, immunosuppressive therapy and supportive care only ${ }^{(9)}$.

IST is often employed as first therapy ${ }^{(10)(11)}$. The most well-studied immunosuppressive regimens in SAA have been based on anti-thymocyte globulin (ATG) ${ }^{(12)}$.

Aim of the study:

To study the effect of the antithymocyte globulin (ATG), methylprednisolone and cyclosporine as a treatment of aplastic anemia.

\section{Patients and methods:-}

This study was conducted in the center of bone marrow transplantation on a sample of 13 Iraqi patients, those patients were already diagnosed as cases of severe aplastic anemia.

Data about sociodemographic factors including age, sex, weight, residency, and occupation were collected. The main presenting symptom and duration of the disease were enquired upon. Every patient had undergone investigations in form of complete blood count, blood film and bone marrow aspiration and biopsy. Patients were screened for hepatitis B and C. HAM'S test was performed to exclude paroxysmal nocturnal hemoglobinuria (PNH) as a secondary cause of aplastic anemia. Biochemical test in form of blood urea serum creatinine and fasting blood glucose were done for each patient.

As a part of preparation of the patients for antithymocyte globulin (ATG) treatment platelets count should be around $50 \times 10^{9} / \mathrm{L}$ so any patient was found to have a platelet count less than this value was transfused with platelets from a relative single donor who was negative for hepatitis B and C serology.

Ciprofloxacin $500 \mathrm{mg}$ twice daily orally and fluconazole $150 \mathrm{mg}$ once daily orally were given during the course of 5 days treatment with ATG to prevent possible infections. Hydrocortisone $100 \mathrm{mg}$ intravenously given 2 hours before the infusion of ATG to overcome the provoked allergic reaction.

All the patients were infused with rabbit type of ATG in a dose of $10-15 \mathrm{mg} / \mathrm{kg}$ for 5 days course under strict aseptic techniques in isolated rooms. It was given in I.V. infusion methods over 8 hours period in the first day and 3-4 hours period in the successive 4 days. The course of ATG treatment was followed by cyclosporine in a dose of $5 \mathrm{mg} / \mathrm{kg} /$ day orally for 5 days and methylprednisolone in a dose of $5 \mathrm{mg} / \mathrm{kg} /$ day intravenously for 5 days also, then after continued on prednisolone orally $60 \mathrm{mg} /$ day which was tapered off gradually over a period of 28 days. Monitoring the patients was done by complete blood count during the course of treatment.

\section{Results:-}

This study included 13 patients with severe aplastic anemia. Male constitute 8(61.5\%), and female 5(38.5\%) of the sample, their age range was 15-30 years. The main presentation of these patients was anemia $61.5 \%$, bleeding in $23.1 \%$ and lastly infection in $15.4 \%$ (table 1 ).

Table 1:-Distribusion of patients according to sex and presentation

\begin{tabular}{|c|c|c|c|c|c|c|}
\hline \multirow{2}{*}{\multicolumn{2}{|c|}{$\operatorname{sex}$}} & \multirow[t]{2}{*}{ age } & \multirow{2}{*}{$\begin{array}{l}\text { Duration of the } \\
\text { disease }\end{array}$} & \multicolumn{3}{|c|}{ Presentation } \\
\hline & & & & anemia & bleeding & infection \\
\hline male & $8(61.5 \%)$ & $15-30$ & $4-24$ & 5 & 2 & 1 \\
\hline female & $5(38.5 \%)$ & $15-30$ & $5-12$ & 3 & 1 & 1 \\
\hline total & $13(100 \%)$ & & & $8(61.5 \%)$ & $3(23.1 \%$ & $2(15.4 \%)$ \\
\hline
\end{tabular}

Table 2 showed that seven (53\%) of patients achieved remission and considered responders: two patients $15.4 \%$ achieved complete remission documented by improvement in blood count (three cell line) and returned to the normal value for their age and sex. Five patients $38 \%$ of patients achieved partial remission. Two patients (40\%) from those who achieved PR had improvement in their HB and platelet count another, other two patients (40\%) had 
improvement in their platelet and WBC counts and the remaining patient (20\%) had improvement in WBC count only.

The seven surviving responders had improvement in the granulocyte levels, 6(85\%) have increase in the hemoglobin levels, 3(42.8\%) have normal platelet level and 2(28.5\%) have normal trilinear blood count.

Table 2:-Responding to treatment

\begin{tabular}{|l|l|l|c|}
\hline Table 2: & \multicolumn{2}{l|}{} \\
\hline Response & Type of response & \multicolumn{1}{c|}{$\mathrm{n}(\%)$} \\
\hline Responders & Complete response & $2(15.4 \%)$ & $7(53.8 \%)$ \\
\cline { 2 - 3 } & Partial response & $5(38.5 \%)$ & \\
\hline Non responders & & $6(46.6 \%)$ \\
\hline Total & & $13(46.6 \%)$ \\
\hline
\end{tabular}

Table 3 showed the effect of treatment with ATG and cyclosporine on the hemoglobin value (HB) values. There was no significant increase in the $\mathrm{HB}$ reading before and after treatment $(\mathrm{P}=0.111)$. But there was a significant change in the platelet counts on treatment with ATG and cyclosporine $(\mathrm{p}=0.012)$. The increase in WBC count at the end of treatment period with ATG and cyclosporine, it was significant $(\mathrm{P}=0.007)$.

Table 3:-Increase in $\mathrm{Hb}$ percent, Platelets count, and WBC in response to treatment by Antithymocyte globulin and cyclosporine

\begin{tabular}{|l|c|c|c|c|c|c|}
\hline & \multicolumn{2}{|c|}{ HB\% } & \multicolumn{2}{c|}{ Platelet count $\times 10^{9} / 1$} & \multicolumn{2}{c|}{ WBC count $\times 10^{9} / 1$} \\
\hline Patients & $\begin{array}{c}\text { Before } \\
\text { treatment }\end{array}$ & $\begin{array}{c}\text { After } \\
\text { treatment }\end{array}$ & $\begin{array}{c}\text { Before } \\
\text { treatment }\end{array}$ & $\begin{array}{c}\text { After } \\
\text { treatment }\end{array}$ & $\begin{array}{c}\text { Before } \\
\text { treatment } \\
\text { treatment }\end{array}$ \\
\hline No.1 & 9 & 13.5 & 34 & 150 & 1.7 & 5.5 \\
\hline No.2 & 8 & 12.5 & 25 & 165 & 0.5 & 3.7 \\
\hline No.3 & 6.5 & 13 & 20 & 50 & 1.5 & 2 \\
\hline No.4 & 8.4 & 10.5 & 46 & 94 & 2.4 & 4.9 \\
\hline No.5 & 10.5 & 11.7 & 10 & 22 & 4.2 & 5 \\
\hline No.6 & 5.8 & 11.2 & 24 & 60 & 1.3 & 2.1 \\
\hline No.7 & 10 & 6 & 23 & 165 & 0.4 & 4 \\
\hline Mean increase & 8.31 & 11.6 & 26 & 100.86 & 1.714 & 3.666 \\
\hline P-value & \multicolumn{2}{|l|}{0.111} & & & & \\
\hline
\end{tabular}

When the response of the patients to treatment with ATG and cyclosporine was assessed in regard to gender no significant difference was found. The response to treatment was stratified by the duration of the disease again it was not significant (table 4).

Table 4:-Distribution of responders according to sex and duration of treatment

\begin{tabular}{|c|c|c|c|c|c|}
\hline variables & & Responders & None-responders & Total & P-value \\
\hline \multirow[t]{3}{*}{ Sex } & Male & 5 & 3 & 8 & \multirow[t]{3}{*}{0.425} \\
\hline & Female & 2 & 3 & 5 & \\
\hline & Total & 7 & 6 & 13 & \\
\hline \multirow{4}{*}{$\begin{array}{l}\text { Duration of } \\
\text { treatment }\end{array}$} & $<6$ months & 0 & 2 & 2 & \multirow[t]{4}{*}{ Not applicable } \\
\hline & 6-12 months & 3 & 4 & 7 & \\
\hline & $\geq 12$ months & 4 & 0 & 4 & \\
\hline & Total & 7 & 6 & 13 & \\
\hline
\end{tabular}

$46 \%$ ( 6 out of 13 ) patients are considered non responders at the end of the follow up period two of them had died at the end of treatment course (one of them developed severe intracranial hemorrhage and the other one severe pneumonia and respiratory failure. 50\% considered non responders 3 out of 6 failed to show any improvement in their blood count during the follow up period and continue to be transfusion dependent. 16.6 (1 out of 6) developed severe allergic reaction to the ATG treatment represented by severe hypotension, rash and dyspnea (anaphylactic 
reaction) which require discontinuation of the drug. intravenous fluid and adrenaline I.V. injection so the patient was considered non responder.

\section{Discussion:-}

Most studies reported a response rate, complete response (CR) plus partial response (PR) ranging from $50 \%$ to $70 \%$ (1). In our study the overall response to the combination of ATG, methyl prednisolone and cyclosporine as a treatment of severe aplastic anemia was 53\%. (15\% CR and 38\% PR). This result was low when compared with other studies done in Europe (74\%) (3), and Germany (70\%) (2). In India an overall response in adult patients was seen in $44.1 \%$ at 6 months, and at 24 months, as many as $67.6 \%$ of the patients (13). and Korea (50\%) (14). This could be explained by the variability in sample size, the duration of the follow up period and degree of the supportive care.

In our study hemoglobin values shows no significant improvement after treatment with ATG. However, $85 \%$ of those who were considered responders show improvement in their HB value during follow up period. This was similar to the results of other studies

Normalization of the platelet counts at the end of our study was observed in 3 patients $42 \%$ of the responders and there was significant improvement in the platelet count from a mean of $(26 \pm 11.3 \times 109 / 1)$ to a mean of $\left(100.86 \pm 59.39 \times 10^{9} / 1\right)$ at the end of study. This result was lower when compared to the Germany study (2). This could be explained by the difference in the sample size and the duration of the follow up period.

Our study showed that there was significant increase in the WBC count over the period of follow up from a mean of $(1.714 \pm 1.296 \times 109 / 1)$ as a baseline measure to a mean $\left(3.666 \pm 1.395 \times 10^{9} / 1\right)$ at the end of the study. This was similar to the result found in the German study (2) where $100 \%$ of the responders had returned to their normal WBC counts.

\section{Conclusion:-}

1. The combination of ATG, methylprednisolone and cyclosporine are an effective treatment for aplastic anemia.

2. This combination of drugs elevates $\mathrm{HB} \%$ value and $\mathrm{WBC}$ count of the surviving responders respectively and it normalizes the platelet count in about half of the responders

3. The time elapsed since the diagnosis of SAA, gender and the presentation of the disease have no influence on the outcome of the treatment.

\section{Refrences:-}

1. Dinca AL, Marginean OC, Melit LE, Damian R, Chincesan M. (2016). Aplastic anemia-therapeutic and deontological aspect. Romanian J of Pediatrics. LXV(1):56-59

2. Frickhofen N, Heimpel H. (2003). Antithymocyte globulin with or without cyclosporine A: 11 year follow up of a randomized trial comparing treatments of aplastic anemia. Blood, 101(4):1236-42

3. Dufour C, Pillon M, Soci_e G, Rov_o A, Carraro E, Bacigalupo A, et al. (2015). Outcome of aplastic anaemia in children. A study by the severe aplastic anaemia and paediatric disease working parties of the European group blood and bone marrow transplant. B.J.H, 169, 565-73

4. Edard C. Gordon Smith and Mitchell Lewis, aplastic anemia, other types of bone marrow failure. In: Hoffbrand AV, Lewis SM, Tuddenham EGD et al, ed. postgraduate hematology oxford butter worth Heinemann. 1999. pp $68-90$

5. 5 Bacigalupo A, Brand R, Oneto R, Bruno B, Socié G, Passweg J. (2000). Treatment of acquired severe plastic anemia bone marrow transplantation compared with immunosuppressive therapy-european group for blood and marrow transplantation experience. Semin Hematol. 37 (1): 69-80

6. Rauff B, Idrees M, Riaz Shah SA, Butt S, Butt AM, Ali L, et al. (2011). Hepatitis associated aplastic anemia: a review. Virol J.; 8: 87

7. Solomou EE, Keyvanfar K, Young NS. (2006). T-bet, a Th1 transcription factor, is up-regulated in T cells from patients with aplastic anemia. Blood. 15,107(10):3983-3991.

8. Nakao S. Immune mechanism of aplastic anemia. (1997) Int J Hematol. 66(2):127-34.

9. Garanitoa MP, Carneiroa JD, Filhoa VO, Scheinbergb P. (2014). Outcome of children with severe acquired aplastic anemia treated with rabbit antithymocyte globulin and cyclosporine A. J Pediatr (Rio J); 90(5): 523-27

10. Guinan EC. Diagnosis and management of aplastic anemia. (2011). 
11. Hematology Am Soc Hematol Educ Program. 2011:76-81.

12. Scheinberg P, Young NS. (2012). How I treat acquired aplastic anemia. Blood. 120:1185-96.

13. Young NS, Calado RT, Scheinberg P. (2006). Current concepts in the pathophysiology and treatment of aplastic anemia. Blood. 108(8): 2509-19.

14. Shah S, Jain P, Shah K, Patel K, Parikh S, Patel A. et al. (1019). Immunosuppressive therapy for aplastic anemia: a single-center experience from western India. Annals of Hematology. 98 (1): 41-46

15. Shin SH, Lee SE, Lee JW. (2014). Recent advances in treatment of aplastic anemia. The Korean J of Intern Med. 29(6):713-26. 